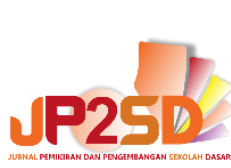

UNIVERSITAS MUHAMMADIYAH MALANG JP2SD (JURNAL PEMIKIRAN

DAN PENGEMBANGAN SEKOLAH DASAR)

http://ejournal.umm.ac.id/index.php/jp2sd

p-ISSN: 2338-1140 e-ISSN: 2527-3043

\title{
Peningkatan Hasil Belajar Siswa Melalui Model Contextual Teaching Learning di Sekolah Dasar
}

\author{
Rini Setyo Wardani ${ }^{\mathrm{a} 1}$, Erna Yayuk ${ }^{\mathrm{b} 2}$, Ratna Nur Kumalasari ${ }^{\mathrm{c} 3}$ \\ a Program Studi Pendidikan Guru Sekolah Dasar, FKIP, Universitas, Indonesia \\ ${ }^{\mathrm{b}}$ Program Studi Pendidikan Guru Sekolah Dasar, FKIP, Universitas, Indonesia \\ ${ }^{c}$ SDN Kauman 1 Malang, Indonesia \\ ${ }^{1}$ rinisetyowardani39@yahoo.com, ${ }^{2}$ ernayayuk17@gmail.com, ${ }^{3}$ alyaaka18@gmail.com
}

\begin{tabular}{ll}
\hline INFORMASI ARTIKEL \\
\hline Riwayat: \\
Diterima & 26 Desember \\
& 2019 \\
Revisi & 18 Januari \\
& 2020 \\
Dipublikasikan & 26 April 2020
\end{tabular}

Kata kunci:

Hasil belajar matematika, Contextual Teaching And Learning

\section{ABSTRAK}

Penelitian ini dilatarbelakangi oleh rendahnya kemampuan matematika anak kelas I sekolah dasar dalam memahami konsep membandingkan dua bilangan. Tujuan dari penelitian ini untuk mendeskripsikan peningkatan hasil belajar matematika siswa kelas I melalui penerapan model contextual teaching and learning. Subjek penelitian ini adalah siswa kelas I C yang berjumlah 28 orang. Rancangan penelitian tindakan kelas ini menggunakan model Kemmis dan Mc Taggart. Teknik pengumpulan data dalam penelitian ini menggunakan lembar observasi, lembar tes, dan dokumentasi selama pembelajaran. Perkembangan proses pembelajaran dari siklus I ke siklus II mengalami peningkatan, baik dari segi aktivitas guru dan siswa selama pembelajaran maupun hasil belajar siswa. Aktivitas guru pada siklus I ke siklus II mengalami peningkatan sebesar $11,77 \%$ dari $76,47 \%$ menjadi $88,24 \%$ dan aktivitas siswa mengalami peningkatan sebesar $17,31 \%$ dari $67 \%$ menjadi $84,31 \%$. Selain itu, ketuntasan hasil belajar siswa secara klasikal dari siklus I ke siklus II juga mengalami peningkatan sebesar $17,86 \%$ dari $75 \%$ menjadi $92,86 \%$. Berdasarkan hasil penelitian tersebut, dapat disimpulkan bahwa model pembelajaran contextual teaching and learning dapat meningkatkan hasil belajar siswa pada muatan matematika Tema 5 Subtema 3.

\section{ABSTRACT}

Keywords:

Mathematicslearning

outcomes, Contextual

Teaching And Learning
This research is motivated by the low mathematical ability at first grade of elementary school students in understanding the concept of comparing two numbers. The purpose of this research is to describe an increase in the mathematics learning outcomes of first grade students through the application of the contextual teaching and learning model. The subjects of this research is the first grade students (C class) that numbers of $28^{\text {th }}$ students. The design of this 


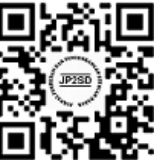

Copyright (C) 2020, Rini Setyo Wardani, dkk

This is an open access article under the CC-BY-SA license

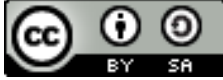

Classroom Action Research uses the Kemmis and $\mathrm{Mc}$ Taggart models. Data collection techniques in this research used observation sheets, test sheets, and documentation during learning. The development of the learning proccess from first cycle to second cycle has increased both in terms of teacher and student activities during learning and student learning outcomes. Teacher activities in first cycle to second cycle increased by $11,77 \%$ from $76,47 \%$ to $88,24 \%$ and student activities increased by $17,31 \%$ from $67 \%$ to $84,31 \%$. Besides that, the completeness of classical student learning outcomes from first cycle to second cycle also increased by $17,86 \%$ from $75 \%$ to $92,86 \%$. Based on the results of this research, it can be concluded that the learning model of contextual teaching and learning can improve student learning outcomes on the mathematical content of theme $5^{\text {th }}$ sub-theme $3^{\text {th }}$.

How to cite: Rini Setyo Wardani, Erna Yayuk, Ratna Nur Kumalasari. (2020). Peningkatan Hasil Belajar Siswa Melalui Model Contextual Teaching Learning di Sekolah Dasar. Jurnal Pemikiran dan Pengembangan Sekolah Dasar, Vol 8 No 1 1-9. doi: https://doi.org/10.22219/jp2sd.v8i1.7970

\section{PENDAHULUAN}

Penerapan Kurikulum 2013 di Indonesia sekarang merupakan salah satu strategi pemerintah untuk terus memperbaiki capaian kualitas pendidikan. Masyarakat di Indonesia peran guru tetap menjadi dominan sekalipun teknologi yang sudah berkembang dan dapat dimanfaatkan dalam proses pembelajaran di sekolah maupun lingkungan sekitar. Halini di karena adanya dimensi dalam proses pendidikan, atau lebih khusus bagi proses pembelajaran, yang diperankan oleh guru yang tidak dapat digantikan oleh teknologi (Sa'ud, 2010). Pemerintah menginginkan adanya peningkatan atau bahkan terjadinya suatu keseimbangan antara kompetensi sikap, pengetahuan, dan, keterampilan yang dimiliki oleh peserta didik sehingga mereka mampu berkompetisi di masa depan melalui penerapan kurikulum 2013 (Majid, 2014:28). Implikasi penerapan kurikulum 2013 tersebut ialah adanya pendekatan pembelajaran tematik terpadu di sekolah dasar. Pembelajaran tematik merupakan pendekatan pembelajaran yang memadukan berbagai kompetensi dari berbagai muatan pelajaran dalam satu tema sehingga siswa sekolah dasar dapat dengan lebih mudah memahami suatu konsep secara utuh. Muatan pelajaran yang dipadukan dalam satu tema pada tingkat sekolah dasar khususnya kelas rendah ialah PPKn, Bahasa Indonesia, Matematika, SBdP, dan PJOK (Majid, 2014:50). Sama halnya dengan yang dikemukakan oleh Suryosubroto (2009:133) menyatakan bahwa pembelajaran tematik merupakan upaya pengintegrasian pengetahuan, keterampilan, sikap, serta pemikiran kreatif menggunakan tema. Penerapan pembelajaran tematik di sekolah dasar menuntut adanya pembelajaran yang terintegrasi antar satu mata pelajaran dengan pelajaran lainnya, bahkan dengan kehidupan siswa sehari-hari.

Berdasarkan hal tersebut, dapat diketahui bahwa matematika merupakan salah satu muatan pelajaran dalam tematik di kelas 1 sekolah dasar. Walaupun matematika telah menjadi satu kesatuan dalam pembelajaran tematik, nampaknya hal itu belum mampu membuat siswa menguasai konsep matematika secara utuh. Padahal matematika merupakan salah satu muatan pelajaran di sekolah yang memiliki banyak manfaat dalam kehidupan sehari-hari. Hal tersebut sesuai dengan pendapat Dyah (2018:588) yang 
menyatakan bahwa matematika tidak menuntut siswa memiliki kemampuan berhitung saja, melainkan dapat membuat siswa terlatih untuk berpikir tingkat tinggi, bernalar logis, dan kritis dalam memecahkan masalah yang dihadapi sehari-hari.

Namun, kenyataan di lapangan menunjukkan bahwa kemampuan matematika anak Indonesia masih rendah. Hal itu terbukti dari hasil penelitian yang telah dilakukan oleh Kemendikbud melalui program Indonesia National Assesment Program (INAP) pada tahun 2016 menunjukkan sekitar 77,13\% siswa SD di seluruh Indonesia memiliki kompetensi matematika yang sangat rendah, yakni $20,58 \%$ cukup dan hanya 2,29\% yang termasuk kategori baik. Hasil penelitian tersebut, ternyata selaras dengan fakta yang ada di lapangan. Berdasarkan hasil wawancara dengan guru kelas IC pada tanggal 9 Januari 2019 ditemukan fakta bahwa siswa mengalami kesulitan dalam memahami materi pada Kompetensi Dasar (KD) 3.3 Membandingkan dua bilangan sampai dua angka dengan menggunakan kumpulan benda-benda konkret. Berdasarkan hasil evaluasi tulis yang dilakukan guru, hanya ada 8 orang siswa (28\%) yang mendapatkan nilai di atas KKM sebesar 75, 5 orang siswa (18\%) mendapatkan nilai sama dengan KKM, dan 15 orang siswa (54\%) mendapatkan nilai di bawah KKM. Hal itu menunjukkan bahwa kemampuan siswa dalam membandingkan dua bilangan cacah masih tergolong rendah.

Padahal menurut penjelasan guru, beliau sudah berusaha menerapkan model pembelajaran cooperative learning dan problem based learning. Bahkan guru juga menggunakan media konkret berupa buah-buahan. Namun semua cara tersebut pada kenyatannya belum berhasil. Beberapa siswa malah bercanda sendiri dengan teman, beberapa siswa lain bermain sendiri dengan buah yang dibawanya, dan siswa lain yang diberi pertanyaan hanya diam saja tidak mau menjawab. Ketidakberhasilan model dan media pembelajaran yang dipilih guru, menuntut guru untuk memilih cara lain yang bisa membuat siswa tertarik dan lebih mudah memahami konsep membandingkan dua bilangan.

Salah satu model yang bisa diterapkan ialah Contextual Teaching and Learning $(C T L)$. Pengajaran dan Pembelajaran Kontekstual atau Contextual Teaching and Learning adalah serangkaian kegiatan pembelajaran yang dikaitkan dengan konteks kehidupan sehari-hari peserta didik, sehingga siswa memperoleh pengalaman belajar secara langsung dan terciptalah pembelajaran yang menarik karena peserta didik merasa apa yang dipelajarinya sangat bermanfaat dalam kehidupannya sehari-hari (Rusman, 2012:187). Hal ini sesuai dengan Nurhadi (dalam Muslich, 2009:41) yang mengemukakan pembelajaran CTL adalah konsep belajar yang membantu guru mengaitkan antara materi pembelajaran dengan situasi dunia nyata siswa dan mendorong siswa membuat hubungan antara pengetahuan yang dimilikinya dengan penerapannya dalam kehidupan mereka sehari-hari. Pada konteks CTL belajar bukan hanya sekedar mendengarkan dan mencatat, akan tetapi belajar merupakan suatu proses berpengalaman secara langsung. Melalui proses berpengalaman itu diharapkan perkembangan siswa terjadi secara utuh, yang tidak hanya berkembang dalam aspek kognitif saja, tetapi aspek afektif dan psikomotorik.

Penerapan model CTL dalam pembelajaran melibatkan adanya tujuh komponen utama yaitu: (1) Modeling, pemodelan untuk memusatkan perhatian siswa, (2) Questioning, bertanya sebagai eksplorasi untuk menuntun siswa pada materi yang akan dipelajari, (3) Learning Community masyarakat belajar atau belajar dalam kelompok dengan berdiskusi, (4) Inquiry melakukan percobaan sederhana, (5) Constructivism membangun pemahaman sendiri, (6) Reflection menindaklanjuti hasil kerja siswa dalam kelompok, dan (7) Authentic assessment atau penilaian autentik (Trianto, 2008:11). 
Berdasarkan tujuh komponen model CTL tersebut, diharapkan apa yang dipelajari siswa dapat lebih bermakna karena mereka mendapatkan suatu pengetahuan berdasarkan pengalamannya sendiri, bukan berasal dari transfer pengetahuan dari guru ke siswa (Suprihatiningrum, 2013:182). Selain itu, model pembelajaran kontekstual ini juga dapat memacu kinerja otak siswa sehingga mereka cenderung lebih aktif karena mereka berusaha untuk mempelajari suatu konsep sekaligus menerapkan dan mengaitkannya dengan dunia nyata. Model pembelajaran kontekstual juga sesuai dengan tahap perkembangan kognitif siswa sekolah dasar yang masih berada di tahap operasional konkret. Penerapan model pembelajaran Contextual Teaching and Learning (CTL) juga sesuai dengan tiga tahapan belajar matematika di sekolah dasar yaitu penanaman konsep dasar pada siswa, pemahaman konsep melalui berbagai media konkret, dan pembinaan keterampilan siswa melalui penyelesaian soal yang berkaitan dengan materi yang telah dipelajari (Heruman, 2013:2). Tiga tahapan tersebut harus dilakukan secara berurutan agar anak sekolah dasar mudah memahami suatu konsep dalam matematika. Selain itu, beberapa penelitian juga menyatakan bahwa model pembelajaran Contextual Teaching and Learning $(C T L)$ dapat meningkatkan hasil belajar matematika siswa.

Penelitian yang dilakukan oleh Markus Alexander Leksair yang berjudul "Peningkatan Hasil Belajar Matematika Melalui Model Pembelajaran Contextual Teaching and Learning (CTL)" menunjukkan bahwa saat pra-tindakan siswa di atas KKM hanya sebesar 34,48\%, kemudian pada siklus I meningkat menjadi 55,17\%, dan pada siklus II menjadi 79,31\% siswa mendapatkan nilai di atas KKM. Selain itu penelitian yang dilakukan oleh Yusuf Nuryanto yang berjudul "Peningkatan Hasil Belajar Matematika Melalui Model Contextual Teaching and Learning (CTL) pada siswa kelas IV SDN Wlingi 02 Kabupaten Blitar" hasilnya menunjukkan bahwa pada siklus I siswa yang mencapai KKM sebesar 57\% dan pada siklus II meningkat menjadi $100 \%$. Berdasarkan pemaparan di atas, tujuan penelitian ini yaitu untuk mengetahui peningkatan hasil belajar siswa menggunakan model Contectual Teaching learning dalam pembelajaran tematik.

\section{METODE}

Penelitian yang dapat dilakukan oleh pendidik salah satunya adalah penelitian tindakan kelas (PTK) karena beberapa alasan diantaranya dapat meningkatkan kualitas pembelajaran, meningkatkan mutu proses pembelajaran dan meningkatkan hasil pembelajaran di kelas. Penelitian tindakan kelas didefinisikan sebagai suatu bentuk kegiatan ilmiah dan bermetode yang dilakukan oleh pendidik didalam kelas dengan mengunakan tindakan-tindakan untuk meningkatkan proses dan hasil pembelajaran yang dtelah dilakukan (Susanti \& Hartanto, 2015).

Dari penjelasan diatas, maka penelitian ini disebut penelitian tindakan kelas (PTK) karena penelitian dilakukan untuk memecahkan masalah pembelajaran di kelas sehingga terjadi perbaikan, peningkatan, dan perubahan pembelajaran ke arah yang lebih baik dan tujuan pembelajaran dapat tercapai secara optimal. Pengertian tersebut sejalan dengan pendapat Rochiati (2014:13) yang menyatakan bahwa PTK merupakan cara guru mencobakan suatu gagasan perbaikan dalam praktik pembelajaran dan melihat pengaruh nyata dari upaya itu. Rancangan atau desain penelitian tindakan kelas (PTK) ini menggunakan rancangan model Kemmis dan Mc Taggart yang memiliki empat tahapan yaitu perencanaan, pelaksanaan, pengamatan, dan refleksi. Keempat tahapan tersebut merupakan serangkaian kegiatan yang harus dilakukan dalam satu siklus. Sehingga 
penelitian tindakan kelas ini sangat penting dilakukan untuk menambah kajian ilmiah dunia Pendidikan.

Tahap perencanaan merupakan persiapan segala sesuatu yang dibutuhkan dalam Penelitian Tindakan Kelas (PTK). Adapun yang dilakukan peneliti yaitu mempersiapkan Rencana Pelaksanaan Pembelajaran (RPP), media pembelajaran, bahan ajar, dan hal lain yang diperlukan. Tahap pelaksanaan merupakan serangkaian kegiatan yang dilakukan dalam menerapkan model pembelajaran Contextual Teaching and Learning (CTL) untuk menguji hipotesis yang telah dibuat. Tahap pengamatan atau observasi merupakan suatu kegiatan kerja sama yang dilakukan guru sebagai peneliti dengan teman sejawat sebagai observer untuk mengamati penerapan model Contextual Teaching and Learning (CTL) dalam pembelajaran dengan mengisi lembar aktivitas guru dan siswa yang sudah dibuat terlebih dahulu. Tahap ini perlu dilakukan untuk mengumpulkan beberapa informasi yang diperlukan dan nantinya diolah menjadi suatu data. Tahap terakhir yaitu refleksi, merupakan suatu kegiatan untuk mengevaluasi pembelajaran yang telah dilakukan menggunakan model pembelajaran yang dipilih. Tujuannya ialah untuk melengkapi hal yang masih kurang dalam pelaksanaan kegiatan belajar mengajar menggunakan model Contextual Teaching and Learning (CTL). Hasil refleksi digunakan sebagai dasar perbaikan pada perencanaan di siklus berikutnya.

Penelitian dilaksanakan dengan dua siklus pada minggu ke 3 Januari 2019 untuk melihat peningkatan hasil belajar siswa pada muatan Matematika KD 3.3. Subjek penelitian ini adalah siswa kelas I C di SD Negeri Kauman 1 Malang pada semester II tahun ajaran 2018/2019. Jumlah siswa sebanyak 28 orang yang terdiri dari 13 siswa lakilaki dan 15 siswa perempuan. Teknik pengumpulan data yang digunakan ialah observasi, tes, dan dokumentasi. Instrumen penelitian yang digunakan yaitu lembar observasi aktivitas guru dan siswa beserta lembar soal tes atau evaluasi.

Data yang akan diambil dalam penelitian ini yaitu: (1) data pelaksanaan model Contextual Teaching and Learning (CTL) yang terdiri dari lembar aktivitas siswa dan lembar aktivitas guru, dan (2) hasil belajar, yang didapat dari tes akhir dalam bentuk soal evaluasi. Analisis data merupakan proses mencari dan menyusun data sehingga dapat diambil suatu kesimpulan untuk mengetahui keefektifan penerapan model Contextual Teaching and Learning (CTL). Penelitian ini menggunakan teknik analisis deskriptif kualitatif dengan menggunakan rumus berikut ini.

\section{a. Lembar pengamatan kegiatan guru dan siswa}

Lembar observasi ini bertujuan untuk

memperoleh data tentang kegiatan guru dan siswa selama penerapan model Contextual Teaching And Learning (CTL). Berikut adalah rumus yang digunakan dalam mengukur aktivitas guru dan siswa selama pembelajaran.

$$
\mathrm{N}=\frac{\text { Skala yang diperoleh }}{\text { Skala maksimal }} \times 100
$$

Keterangan:

$\mathbf{N}$ : Nilai yang diperoleh dari kegiatan guru selama menerapkan model CTL

Skala yang diperoleh: Skor yang diperoleh dari banyaknya deskriptor yang muncul

Skala maksimal: Jumlah skor keseluruhan dari aspek yang ditetapkan

\section{b. Hasil belajar siswa}

Hasil belajar siswa diperoleh melalui 
penskoran hasil tes yang dilaksanakan pada akhir pembelajaran. Skor maksimal yang diperoleh adalah 100 .

Rumus yang digunakan dalam penskoran adalah sebagai berikut.

$$
\mathrm{N}=\frac{\text { Skala yang diperoleh }}{\text { Skala maksimal }} \times 100
$$

Keterangan:

$\mathbf{N}$ : Nilai evaluasi siswa

Skala yang diperoleh: Jumlah jawaban benar siswa pada soal evaluasi

Skala maksimal: Jumlah skor keseluruhan

Dalam penelitian ini, kriteria ketuntasan yang digunakan adalah ketuntasan individual dan ketuntasan klasikal. Berikut uraian dari standar ketuntasan individual dan standar ketuntasan klasikal.

\section{1) Ketuntasan individu}

Siswa dikatakan tuntas belajar apabila memperoleh nilai di atas KKM, sedangkan siswa dikatakan belum tuntas apabila nilai di bawah KKM. Penetapan skor kriteria ketuntasan individual adalah nilai 75 .

\section{2) Ketuntasan klasikal}

Peningkatan hasil belajar siswa dapat diketahui dari hasil akhir pembelajaran siswa dengan kriteria ketuntasan klasikal 75\%. Untuk mengetahui ketuntasan belajar siswa digunakan rumus sebagai berikut.

$$
\% \mathrm{KK}=\frac{\sum \text { Siswa yang tuntas }}{\sum \text { Seluruh siswa }} \times 100 \%
$$

\section{HASIL DAN PEMBAHASAN}

Penelitian ini dilaksanakan pada tanggal 15 Januari 2019 untuk prasiklus, 16 Januari 2019 untuk siklus I, dan 17 Januari 2019 untuk siklus II. Berdasarkan penelitian yang telah dilakukan, diperoleh hasil bahwa pembelajaran menggunakan model CTL mengalami peningkatan baik dari segi aktivitas guru dan siswa selama pembelajaran maupun hasil belajar siswa. Peningkatan tersebut dapat dilihat dari tabel di bawah ini.

Tabel 1. Peningkatan aktivitas guru selama pembelajaran.

\begin{tabular}{lcc}
\hline \multicolumn{1}{c}{ Aspek } & Siklus I & Siklus II \\
\hline Skor yang diperoleh & 13 & 15 \\
Skor Maksimal & 17 & 17 \\
Persentase skor & $76,47 \%$ & $88,24 \%$ \\
\hline
\end{tabular}

Berdasarkan tabel di atas dapat diketahui bahwa aktivitas guru dalam penerapan model CTL di siklus I dan siklus II mengalami peningkatan sebesar 11,77\%. Hal itu dapat terlihat dari jumlah deskriptor yang muncul dalam setiap siklus. Ada 13 deskriptor yang muncul di siklus I menjadi 15 deskriptor yang muncul di siklus II. Peningkatan itu terjadi karena setelah melakukan siklus I, guru dan teman sejawat melakukan refleksi agar di siklus II guru dapat lebih optimal dalam menerapkan model CTL dalam kegiatan belajar 
mengajar. Selain aktivitas guru yang meningkat, berikut juga akan disajikan peningkatan aktivitas siswa dalam penerapan model CTL.

Tabel 2. Peningkatan aktivitas siswa selama pembelajaran.

\begin{tabular}{lcc}
\hline \multicolumn{1}{c}{ Aspek } & Siklus I & Siklus II \\
\hline Skor yang diperoleh & 34 & 43 \\
Skor Maksimal & 67 & 51 \\
Persentase skor & $67 \%$ & $84,31 \%$ \\
\hline
\end{tabular}

Berdasarkan tabel di atas dapat diketahui bahwa aktivitas siswa dalam penerapan model CTL di siklus I dan siklus II mengalami peningkatan sebesar 17,31\%. Hal itu dapat terlihat dari jumlah deskriptor yang muncul dalam setiap siklus. Ada 34 deskriptor yang muncul di siklus I menjadi 43 deskriptor yang muncul di siklus II.

Setelah melaksanakan observasi terkait kegiatan belajar mengajar yang dilakukan guru dan siswa dalam penerapan model CTL, maka kegiatan selanjutnya adalah mengadakan tes hasil belajar dengan memberikan soal evaluasi pada setiap siswa. Bentuk soal pada lembar evaluasi ialah isian singkat terkait konsep membandingkan dua bilangan pada Kompetensi Dasar 3.3 yang terdapat di Tema 5 Subtema 3. Perbandingan nilai hasil tes siswa ketika prasiklus, siklus I, dan siklus II dapat dilihat pada diagram berikut ini.

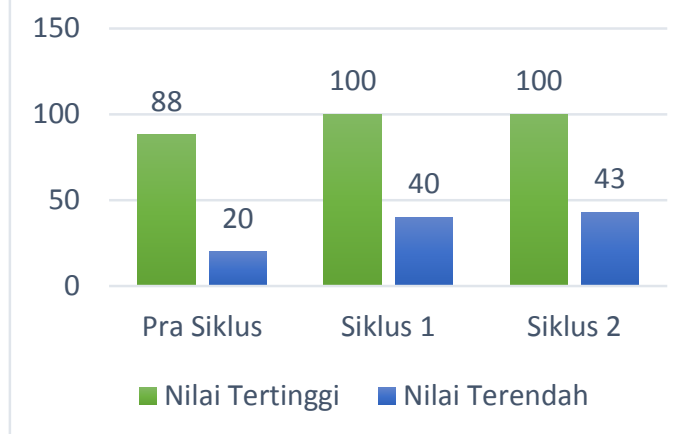

\section{Diagram 1. Perbandingan nilai prasiklus, siklus I dan siklus II}

Berdasarkan diagram tersebut, dapat diketahui bahwa nilai terendah siswa dari pra siklus, siklus I, dan siklus II selalu mengalami peningkatan. Nilai terendah di prasiklus ialah 20, kemudian setelah siklus I meningkat 20 poin menjadi 40, dan di siklus II meningkat 3 poin menjadi 43. Selain itu, nilai tertinggi dari pra siklus ke siklus I mengalami peningkatan sebesar 12 poin dan dari siklus I ke siklus II tetap karena telah mencapai nilai maksimal yaitu 100. Berdasarkan hasil tersebut dapat diketahui pula bahwa nilai rata-rata kelas juga pasti mengalami peningkatan. Ketika pra siklus, nilai ratarata kelas hanya 68,36 , kemudian pada siklus I 84,54 dan pada siklus II meningkat lagi menjadi 94,54. Nilai rata-rata kelas itu sudah melebihi KKM kelas untuk muatan matematika yang sudah ditetapkan guru sebesar 75. Selain itu, data terkait dengan ketuntasan belajar klasikal siswa dari pra siklus, siklus I, dan siklus II dapat dilihat pada diagram berikut ini. 


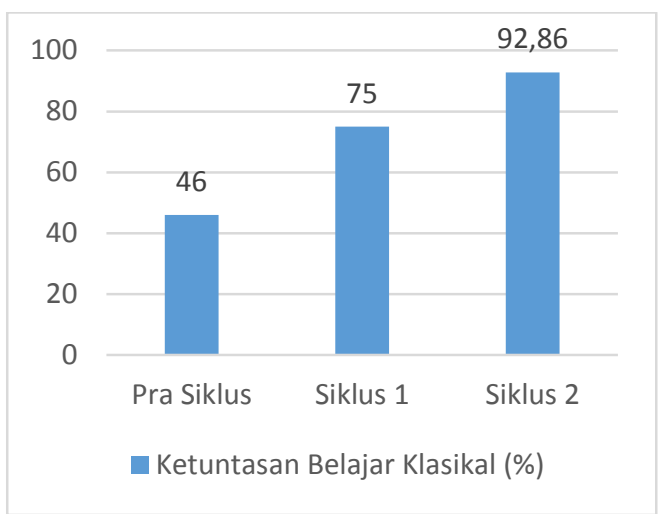

\section{Diagram 2. Ketuntasan Belajar Klasikal Siswa.}

Berdasarkan diagram tersebut dapat diketahui bahwa ketuntasan belajar klasikal siswa mengalami peningkatan yang signifikan. Pada tahap pra siklus ketuntasan belajar masih belum optimal karena hanya 13 siswa yang tuntas sehingga persentasenya $46 \%$. Kemudian pada siklus I banyak siswa yang tuntas adalah 21 orang sehingga persentasenya mencapai $75 \%$ dan pada siklus II siswa yang tuntas ada 26 orang sehingga persentasenya menjadi $92,86 \%$. Berdasarkan data pada tabel maupun diagram yang telah disajikan tersebut, dapat diketahui bahwa penerapan model contextual teaching and learning (CTL) pada siswa kelas I C SD Negeri Kauman 1 Kota Malang dalam muatan pelajaran Matematika KD 3.3 di Tema 5 Subtema 3 telah sesuai.

Penerapan model tersebut dapat membuat siswa lebih aktif. Hal itu terbukti dengan terlaksananya tujuh komponen dalam penerapan model CTL yang disampaikan Trianto (2008), mampu membuat siswa untuk membangun pengetahuan mereka sendiri dan mengaitkannya dengan kehidupan sehari-hari melalui kegiatan percobaan sederhana dan diskusi kelompok. Melalui beberapa kegiatan tersebut, selama pembelajaran siswa terlihat lebih bersemangat dan berantusias. Model CTL tersebut menfokuskan mengenai keterlibatan siswa secara maksimal agar dapat menemukan muatan materi yang sedang dipelajari dan menyambungkan dengan keadaan kehidupan yang sebenarnya, sehingga siswa dimotivasi agar dapat menerapkan dalam kehidupan sehari-hari siswa.

Keaktifan siswa selama pembelajaran itu ternyata berpengaruh terhadap hasil belajar siswa di akhir pembelajaran yang mengalami peningkatan. Peningkatan yang terjadi secara signifikan itu menunjukkan bahwa adanya pengaruh penerapan model CTL terhadap kemampuan siswa dalam membandingkan suatu bilangan. Peningkatan yang terjadi pada hasil belajar siswa dari setiap siklusnya menunjukkan bahwa hal tersebut sesuai dengan penelitian Markus (2017) yang menyatakan bahwa model contextual teaching and learning sesuai dan dapat meningkatkan hasil belajar matematika siswa. Selain itu, hasil penelitian ini juga selaras dengan penelitian Yusuf (2011) yang menyatakan bahwa model contextual teaching and learning dapat meningkatkan hasil belajar matematika siswa sekolah dasar.

Selain terfokus pada hasil belajar siswa, keberhasilan proses belajar mengajar itu juga merupakan salah satu aspek penting dalam penelitian ini. Perwitasari (2017) menyatakan bahwa untuk meningkatkan hasil belajar siswa diperlukan penguasaaan konsep melalui kegiatan pembelajaran yang memadukan berbagai bidang studi ke dalam satu tema yang terkait dalam kehidupan sehari-hari. Keterlaksanaan proses belajar mengajar di kelas menggunakan model contextual teaching and learning ternyata juga mengalami peningkatan. Hal itu terbukti dari persentase aktivitas guru dan siswa dalam penerapan model CTL pada siklus I dan siklus II. Berdasarkan hal itu dapat dikatakan 
bahwa model contextual teaching and learning dapat membuat pembelajaran berlangsung secara lebih efektif dan efisien. Selain itu, penerapan model contextual teaching and learning yang sesuai dengan tahapan belajar matematika di sekolah dasar menurut Heruman (2013) ternyata benar-benar mampu membuat anak lebih mudah dalam memahami suatu konsep dalam matematika.

\section{SIMPULAN}

Berdasarkan hasil penelitian dan pembahsan dapat diketahui bahwa dengan menerapkan model Contextual Teaching and Leraning (CTL) dapat meningkatkan hasil belajar siswa kelas I C SD Negeri Kauman 1 Malang pada muatan Matematika KD 3.3 membandingkan dua bilangan sampai dua angka dengan menggunakan kumpulan bendabenda konkret di Tema 5 Subtema 3. Model CTL merupakan salah satu model pembelajaran yang dapat memberikan pengalaman belajar siswa yang secara langsung yang dilakukan melalui pengamatan. Selain pembelajaran matematika, model CTL dapat digunakan untuk pembelajaran lainnya, dikarenakan identic dengan pembelajaran yang menarik dan mengaktifkan siswa dalam proses pembelajaran.

\section{REFERENSI}

Heruman. 2013. Model Pembelajaran Matematika di Sekolah Dasar. Bandung: PT Remaja Rosdakarya.

Kusumawardani, Dyah Retno, dkk. 2018. Pentingnya Penalaran Matematika dalam Meningkatkan Kemampuan Literasi Matematika. PRISMA Prosiding Seminar Nasional Matematika.

Leksair, Markus Alexander. 2017. Peningkatan Hasil Belajar Matematika Melalui Model Pembelajaran Contextual Teaching and Learning. Jurnal Pendidikan Guru Sekolah Dasar Edisi 9 Tahun ke-6.

Majid, Abdul. 2014. Pembelajaran Tematik Terpadu. Bandung: PT Remaja Rosdakarya.

Nuryanto, Yusuf. 2011. Peningkatan Hasil Belajar Matematika Melalui Model Contextual Teaching and Learning (CTL) pada Siswa Kelas IV SDN Wlingi 02 Kabupaten Blitar. Skripsi tidak diterbitkan. Malang: FIP UM.

Perwitasari, S., \& Wahjoedi, W. (2017). Bahan Ajar Tematik Berbasis Kontekstual Untuk Siswa Sekolah Dasar. In Prosiding Seminar Nasional Mahasiswa Kerjasama Direktorat Jenderal Guru dan Tenaga Kependidikan Kemendikbud 2016.

Rusman. 2012. Model-Model Pembelajaran. Jakarta: PT Rajagrafindo Persada.

Sa'ud, U. S. (2010). Pengembangan Profesi Guru. Bandung: Alfabeta.

Suprihatiningrum, Jamil. 2013. Strategi Pembelajaran Teori dan Aplikasi. Jogjakarta: Ar-Ruzz Media.

Suryosubroto. (2009). Proses Belajar Mengajar di Sekolah. Jakarta: PT.Rineka Cipta

Susanti, E., \& Hartanto, D. (2015). Peningkatan Kompetensi Guru Melalui Penerapan Penelitian Tindakan Kelas (PTK) Dalam Pendidikan Islam. POTENSIA: Jurnal Kependidikan Islam, 14(1), 151-174.

Trianto. 2008. Mendesain Pembelajaran Kontekstual (CTL) di Kelas. Surabaya: Cerdas Pustaka Publisher.

Wiriaatmadja, Rochiati. 2014. Metode Penelitian Tindakan Kelas untuk Meningkatkan Kinerja Guru dan Dosen. Bandung: PT. Remaja Rosdakarya. 